\title{
ARCHAEOLOGY OF GENEROSITY
}

Katia Teonia Costa de Azevedo ${ }^{1}$

During the period I worked, enthusiastically, as a Substitute Professor in the Latin Department between the years of 2006 and 2008, I could join the notable company of the Professor Pedro Paulo Funari, while I lectured the discipline 'Classical Matrices', which had been recently implemented as a compulsory subject in the university programme of the Languages Course of the Universidade Federal Fluminense.

Due to the academic load of the discipline (60 hours shared with the Greek Department), I felt the need of searching for a material that could briefly introduce the pupils into the Greco-Roman universe. Therefore, I selected the book called Grécia e Roma (2002) written by Pedro Paulo Abreu Funari. The concise and introductive approach was of paramount importance for the book adoption and it certainly had to take part in the bibliographical references of the course, which was offered in the first semester for the students of various Languages Courses at the University (except for the ones who took Latin as a major). Most of those students were experiencing for the first time a formal contact with the GrecoRoman Culture.

For that matter, Professor Funari's immortalized presence accompanied me through his work entitled Grécia e Roma (2002), a delicate book which belonged to the collection called Repensando a História, coordinated by Jaime Pinsky. Such book offers a global overview of the aspects of the private and public life, culture, thoughts, mythology, love and sexuality, as the subhead of the book can enlighten.

Professor Funari was our guide in such a pleasant and enriching experience through the Classcial Antiquity, a journey which was conducted by the transparency of his words which evidences his didactical characteristics not only by his language but also through the presentation and selection of the themes debated along the book. Such a treatment of the material is complemented by original sources which are made by evidences and written elements, which provides the enrichment of some of the topics addressed, take the role of the woman in the Greek

\footnotetext{
${ }^{1}$ Assistant Professor, Federal University of Rio de Janeiro, Rio de Janeiro, Brazil. E-mail: katiateonia@letras.ufrj.br
} 
society for instance (Funari, 2002: 55, 104-106). The use of written documents made feasible the anticipation of the contact with representative authors of the Latin Literature, such as Catullus and Ovid (Funari, 2002: 106), such poets are studied much further along the course. Last but no least, it is also offered by the end of the book a timeline in order to help the contextualization and a bibliographical reference which complements the presented content. Those are elements that conform with the introductory and didactical nature of the book Grécia e Roma.

The invitation to take part in the Classical Languages Seminar of 2007, at the Language Institute of the Universidade Federal Fluminense, in which the Professor Funari lectured the talk entitled The Latin Inscriptions and a Study of the Roman Society, was the merriest occasion in which I could have met him in person and notice his skilled experience in the classroom with the use of his own book. From that moment, I could also witness his generosity and kindness, all noticed by the way he listened and his willingness to help and offer other materials of his own that could be useful to my course (and they were!).

Those brief words are the sincere expression of my gratitude and admiration to the dear Professor Pedro Paulo Abreu Funari. I congratulate the admirable initiative of the professor Glaydson José da Silva for such special opportunity to make public my affection to the one who made us connected in such a praiseworthy laudatory edition. 